\title{
PROFIT TAX OR INCOME TAX? OPTIONS FOR FISCAL OPTIMIZATION OF ROMANIAN SMALL COMPANIES
}

\author{
Doina Păcurari \\ "Vasile Alecsandri" University of Bacău \\ doinap@yahoo.com
}

\begin{abstract}
Entrepreneurs usually seek for solutions to reduce their tax burden. We can speak about tax optimization as long as these solutions are in accordance with the law; if they are not, they obviously fall into the area of fiscal fraud. This paper addresses the issue of taxation applicable to the Romanian micro-enterprises. These are small entities that fulfil certain conditions regarding total turnover, equity and domain of activity. Although the provisions applying to micro-enterprise taxation were elaborated, among others, with the intention to reduce tax evasion, they also allow the micro-enterprises with losses to avoid tax payment. In a country with low purchasing power and a great number of taxes and fees like Romania, the entrepreneurs are tempted to use any kind of method to reduce the payments due to the state budget. The micro-enterprise owners make no exception in this matter.
\end{abstract}

\section{Keywords}

micro-enterprise; profit tax; income tax; tax evasion; fiscal optimization

\section{JEL Classification}

G30; M10

\section{Introduction}

Applicable tax on either profit or income is the main taxation method established for Romanian legal entities and represents an important source of revenues to the state budget. However, the actual amount of these collected revenues to the budget depends on the legal entities' degree of compliance in their capacity as taxpayers. It is a fact that a decrease in tax collection may impact on the public services provided by state and even affect the honest taxpayers, as the state will try to further tax these in order to secure budgetary resources (Alm, 2012). Given the fact that presently, companies are seriously affected by the prolonged economic crisis, their owners have got every incentive to seek solutions to reduce their tax burden. Their actions may get to fall into the area of tax evasion or may represent a form of taxation avoidance allowed by law, as shown below.

\section{Tax evasion and fiscal optimization}

Tax evasion refers to intended total or partial lack of compliance with tax obligations. It means evading tax obligations altogether or dealing with them fraudulently with the purpose of reducing the amounts payable to the state budget.

Unlike the actions pertaining to tax evasion, fiscal optimization is licit, permitted by law, even if its ultimate goal is still reduction of taxes owed to the budget. Fiscal optimization generally aims at placing the taxpayer in a more favourable system of taxation or at reducing their taxable base. 
Literature contains numerous papers on the topic of tax evasion. A number of articles dealing with the ethics of tax evasion are especially noteworthy, in our opinion. For instance, having analyzed his predecessors' work on the subject, McGee (2006) has summarized three basic approaches regarding the ethics of tax evasion. According to the first approach, tax evasion is unethical whatsoever. This is because individuals have obligations towards the state, towards the other members of their community and even towards God, having to show compliance with their leaders' decisions. The anarchy-based second approach sees tax evasion as ethical whatsoever on the premises that the state is illegitimate, corrupt and vicious because it forces individuals to give up part of their wealth or income. The third approach ascertains that tax evasion is sometimes ethical, namely when the government is corrupt or does not use the public money for the benefit of the people (Dell'Anno, 2009).

Tax conformation is primarily determined by fear of state controls and by applicable penalties in case of law infringement. Nevertheless, taxpayers' attitude is also influenced by they way they are treated by the state (Feld, 2002) and by the degree of corruption in the politicians who decide economic policies (Goerke, 2008; Dell'Anno, 2009).

As for the degree of compliance, the taxpayer's behaviour may be:

- licit with respect to taxation, meaning integral accomplishment of tax obligations;

- contravention illicit, that is failure to accomplish tax obligations to some extent, either through ignorance or through tax avoidance actions such as: profit split, tax deferral or shift to a more profitable but wrong taxation method;

- penal illicit, involving intended avoidance of tax obligations that results in significant social or economic consequences.

The last two are manifestations of tax evasion that make taxpayers liable to fines or penal sanctions, depending on the case.

Globalized business expansion has been offering new opportunities for corporate tax evasion (Alm, 2012), which makes it difficult for all states to fight against the phenomenon.

Moreover, attitude towards tax evasion often differs from one country to another, depending on religion, individual beliefs and also on the geo-political context (McGee, 2007, McGee et al, 2007; Robinson \& Slemrod, 2012). According to some researchers' opinion, including Ho and Wong (2008), appropriate public education focusing on ethics would help to increase the degree of tax compliance.

\section{Taxation of the Romanian companies}

As a general rule, Romanian legal entities are due to pay profit tax to the budget. However, if they fall into the micro-enterprise category, payment is due as tax on the obtained incomes. Differentiation does not apply to foreign businesses operating in Romania, which must pay profit tax irrespective of their size or type of activity.

\subsection{Profit tax}

Companies due to pay profit tax in Romania owe a $16 \%$ tax rate which applies to taxable profit computed as the difference between taxable incomes and deductible expenses. Non-taxable incomes as well as non-deductible expenses or limited deductible expenses are specified in the Fiscal Code (2013), a document that has been modified many times since its adoption by law in 2003.

Profit tax is calculated quarterly based on incomes and expenses realized from the beginning of the fiscal year, which coincides with the calendar year in Romania. Starting with the second quarter of the year, tax owed to the budget represents the 
difference between the tax calculated at the end of the reporting quarter and the tax calculated at the end of the previous quarter. The adjustment of profit tax per fiscal year is to be made before March of the following year, when is the deadline for transmission of the annual profit tax declaration. If losses are recorded, these are to be recovered from the taxable profits in the following quarters within a period of 7 years at the most.

Unlike most companies that calculate profit tax on quarterly basis, some put into practice "the annual profit tax with anticipatory payments" system. These belong to the banking industry, to which companies willing to do so have been adding since 2013. The method consists in determining the profit tax for the ongoing year through an update by the inflation rate for profit tax payable for the preceding fiscal year. The resulting tax amount is divided by four, which in turn gives the quarterly anticipatory payments. After the fiscal year closure, the annual tax is then concluded and the ensuing differences need to be paid by the deadline for submission of the annual profit tax declaration.

\subsection{Tax on incomes of micro-enterprises}

If certain conditions are met, small companies are due to pay income tax (commonly referred to as turnover tax). This is called tax on incomes of micro-enterprises. The tax rate amounts to $3 \%$ and the tax is calculated quarterly.

The conditions that must be met cumulatively by a company in order to be categorized as micro-enterprise are as follows:

C1) it must obtain incomes that are less than the equivalent in national currency of 65,000 euros;

C2) it must not get incomes from banking, consulting, management, gambling, insurance/reinsurance activities or from capital markets (except brokers and insurance agents' intermediation);

C3) its capital must be owned by entities other than the state or the local authorities;

C4) it must not be in the process of dissolution with liquidation (registered at the Trade Register or in a court of law).

The application of one of the two taxation methods (profit tax or income tax) must take place from the beginning of the fiscal year. Compliance to C1 and C2 criteria is verified based on the data recorded at the end of the previous fiscal year. It should be noted that one of the reasons for which consulting and management services were classified as exempt activities is that given their type of activity, they generate significant profits. In other words, they may produce income without much expense and the state would have much to lose if such activity were taxed at $3 \%$ of incomes instead of $16 \%$ of profit. The other exempt activities are specific to companies supervised by regulating bodies in the banking, insurance/reinsurance and gambling industries.

In the case of newly established companies, they will be considered micro-enterprises if they fulfil the condition referring to capital and if they state that incomes less than 65,000 euros are going to be obtained. Exceptions to the rule are those newly established companies that declare activity types falling into the exempt category (condition C2) above.

Yet another exception consists of companies with social capital exceeding 25,000 euros. These may opt for profit tax ever since their establishment, regardless of the estimated or actual turnover. The taxation system is to be maintained only if these companies do not decrease their social capital below the 25,000 euros limit during their existence. 
The calculation base for the tax on incomes of micro-enterprises consists of the total revenues achieved during the quarter, less the following income types which are considered non-taxable:

o incomes associated with the costs of completed production or services in progress;

0 incomes from the production of tangible and intangible assets;

o subsidies for operating activities;

o incomes from provisions and adjustments for depreciation or loss of value;

o incomes from cancellation of interest or penalties dealt with as non-deductible expenses when calculating profit tax (if the company paid profit tax in the preceding years);

o incomes from indemnifications granted by insurance/reinsurance companies for the damages caused to own stocks or tangible assets.

The taxable base is to be reduced if the company buys cash registers for its own needs. Thus, their purchase price is to be deducted from the total taxable income in the quarter in which they are put into service, consequently reducing the due tax amount.

Starting with 2013 (i.e. from the $1^{\text {st }}$ of February, 2013), income tax has been mandatory for micro-enterprises. This taxation method had been optional before and had been considered a facility granted to small businesses, due to its low tax rate and simple calculation procedure. The tax rate has been maintained at a low level (see Table 1) since its establishment, noting that in 2010 this taxation method was not put into practice.

Table 1 Evolution of the taxable base of the tax on incomes of micro-enterprises

\begin{tabular}{|c|c|c|c|c|c|c|c|c|c|c|}
\hline Year & 2004 & 2005 & 2006 & 2007 & 2008 & 2009 & 2010 & 2011 & 2012 & 2013 \\
\hline $\begin{array}{c}\text { Tax rate } \\
(\%)\end{array}$ & 1.5 & 3 & 3 & 2 & 2.5 & 3 & $\mathrm{n} / \mathrm{a}$ & 3 & 3 & 3 \\
\hline
\end{tabular}

Source: Fiscal Code, Title IV, available online at

http://static.anaf.ro/static/10/Anaf/Legislatie_R/Arhiva_cod_fiscal.htm

The Fiscal Code (2013) contains special provisions for the situation in which turnover exceeds the threshold of 65,000 euros during the year. In such case, the company owes profit tax starting with the quarter in which the limit was exceeded. The profit tax will then be calculated based on incomes and expenses made from the beginning of the year.

If a micro-enterprise benefits from the income tax system and agrees to maintain it, it will have to make efforts to observe the above conditions, particularly C1 and C2. Whenever the company is at risk of breaching one of the two conditions, the managers may at the limit consider solutions for fiscal optimization, be it through inaction in order to avoid the recording of income that would result in exceeding the EUR 65,000 limit, be it through avoidance of activities not admitted in the case of micro-enterprises.

From a practical viewpoint, these solutions require either refusal of orders / contracts generating future income or law violation by not recording the entire incomes in accounting, in which case we speak of fiscal evasion.

In the case of a newly established company which expects to record incomes that will only slightly exceed the expenses, a fiscal optimization solution to avoid tax on incomes of micro-enterprises is advisable. For example, for incomes of 10,000 euros (taxable both in terms of profit tax and tax on incomes of micro-enterprises), to which 9,000 euros correspond in deductible expenses, the income tax amounts to 300 
euros (10,000 euros x $3 \%$ ), whereas profit tax is only 160 euros (1,000 x 16\%). However, if the new company expects to achieve a high rate of profitability, it is advisable to opt for taxation system applicable to micro-enterprises.

\subsection{Tax avoidance by the micro-enterprises with losses}

Although the tax rate is not high (currently at 3\%), it represents an extra amount to pay for companies with losses. This would not be required if the said companies paid profit tax, hence their desire to avoid this taxation system.

Analyzing the conditions to be met for inclusion in the micro-enterprise category, it is noted that there are two solutions to avoid tax:

S1) capital increase above the 25,000 euro limit;

S2) recording revenue from activities such as those referred to under the C2 condition. The other two options involving non-compliance to the C1 and C3 conditions were not taken into consideration. More exactly, the condition C1 would be about exceeding the limit for turnover, which does not depend on the management's decision but on the market situation (it is less plausible for a taxpayer to record fictitious additional income). The breach of the C3 condition would imply that part of the share capital be taken over by the state or the local authorities, thus making this alternative out of easy reach for small businesses .

The here above S1 solution requires a significant financial effort for a microenterprise, in circumstances in which many such entities have got a share capital amounting to 200 RON (about 50 euros), the minimum allowable capital in Romania. Therefore, the most accessible solution is the second, namely recording revenue deemed as unacceptable in the case of micro-enterprises. To put it into practice, it is enough to draw one contract of consultancy alone, irrespective of its size. Consequently, tax payment may be avoided without infringing on the law. The only requirement is for the company to include consulting or management services within its activity types. Nevertheless, the rules and regulations implementing the Fiscal Code stipulate that during fiscal inspections the control bodies analyze the form and content of consultancy contracts in order to determine whether they are real or not and to expose any attempts to evade tax. To sum up, fictitious or not properly drawn contracts may generate concern upon inspection conducted by the tax authorities.

\section{Conclusions}

Subject to the fiscal benefits that may be obtained, a small business may try to implement fiscal optimization solutions in order to fall into or, on the contrary, bypass the micro-enterprise category, depending on the case. This depends on the business' rate of profitability.

Micro-enterprises with losses are most motivated to avoid the income tax system. In order to do this, they have two alternatives at hand: increasing their capital or, recording income classified as legally unacceptable, i.e. income from banking, insurance/reinsurance, consulting and management or gambling activities. The first solution is more challenging, as it involves a financial effort and legal formalities to be carried out at the Trade Register Office. In contrast, the second solution is more straightforward and the company willing to put it into practice simply has to include one of the exempt activities within its types of activity. Out of these, only the consulting and management activities are within the reach of any business.

Initially conceived as an optional alternative to taxation in order to support the small businesses, the tax on incomes of micro-enterprises has become less approved of ever since it turned mandatory and since the financial performance of the companies 
started to be seriously affected by the economic crisis. In the initial phase, the manager of a firm that met the specific conditions applying to micro-enterprises could select the tax type to observe, thus optimizing his tax burden. However, presently lacking such option, the manager will be tempted to force maintain or breach the said conditions, depending on the case.

\section{References}

Alm, J. (2012), Measuring, explaining, and controlling tax evasion: lessons from theory, experiments, and field studies, International Tax and Public Finance, 19(1), 54-77.

Dell'Anno, R. (2009), Tax evasion, tax morale and policy maker's effectiveness, The Journal of Socio-economics, 38, 988-997.

Feld, L. P., Frey, B. S. (2002), Trust breeds trust: How taxpayers are treated, Economics of Governance, 3, 87-99.

Fiscal Code (2013), approved by the Law no.571/2003 regarding the Fiscal Code, with subsequent amendments and supplements, available on http://static.anaf.ro/static/10/Anaf/Legislatie_R/Cod_fiscal_norme_2013.htm (RO).

Goerke, L. (2008), Bureaucratic corruption and profit tax evasion, Economics of Governance, 9, 177-196.

Ho, D., Wong, B. (2008), Issues on compliance and ethics in taxation: what do we know?, Journal of Financial Crime, 15(4), 369-382.

McGee, R. W. (2006), Three Views on the Ethics of Tax Evasion, Journal of Business Ethics, 67(1), 15-35.

McGee, R. W. (2007), Changing Attitudes toward the Ethics of Tax Evasion: An Empirical Study of 10 Transition Economies, Andreas School of Business Working Paper Series, 4(April), 1-23.

McGee, R. W., Basic, M., Tyler, M. (2007), The Ethics of Tax Evasion: A Comparative Study of Bosnian and Romanian Opinion, Andreas School of Business Working Paper Series, 10(October), 1-16.

Robinson, L., Slemrod, J. (2012), Understanding multidimensional tax systems, International Tax and Public Finance, 19(2), 237-267. 